\title{
Type-1 Angiotensin II Receptor-Associated Protein
}

National Cancer Institute

\section{Source}

National Cancer Institute. Type-1 Angiotensin II Receptor-Associated Protein. NCI

Thesaurus. Code C101502.

Type-1 angiotensin II receptor-associated protein (159 aa, $\sim 17 \mathrm{kDa}$ ) is encoded by the human AGT RAP gene. This protein plays a role in the negative regulation of angiotensin receptor signaling. 